\title{
特集 巨赤芽球性資血
}

\section{薬剤による巨赤芽球性貧血}

藤耐成 德**

\section{緒言}

血液中の細胞成分である赤血球や白血球はお のおのの芽細胞が骨髄中で数回の細胞分裂を経 ながら成熟し, 形態的, 機能的に完備した後に 末梢血液中に出現する。したがって骨䯣での一 定の細胞分裂，その前段階としての DNA 複製 は正常造血に必須の過程であり，これが障害さ れることにより貧血や白血球減少症などの血液 疾患が括こる。芽細胞の DNA 複製には DNA 合成系酵素汇よる核酸前駆物質の生合成を必要 とし, ビタミン $\mathbf{B}_{12}\left(\mathrm{VB}_{12}\right)$ や葉酸がその生合 成に関与している， $\mathrm{VB}_{12}$ や葉酸が火そすると 巨赤芽球性負血 ${ }^{1)}$ になるが，胃内因子の分泌異 常による $\mathrm{VB}_{12}$ の吸収障害によっておこる貧血

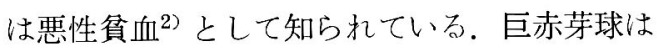
DNA 合成が阻害されて括り，成熟障書や骨䯣 内崩壊がおこる，巨赤芽球（箃密には巨赤芽球 様細胞 megaloblastoid cell と呼ぶべきものも 含む) は抗白血病剤や抗てんかん剂などの投与 時，ある種の中毒の場合にも骨髄中に出現する ことが報告されている。ここではこれら薬剤の 核酸合成に対する作用機序と巨赤芽球産生の関 係を $\mathrm{VB}_{12}$ や葉酸欠乏による巨赤芽球の核酸代 謝と対比させて考察してみたい。

\section{I. 巨赤芽球の核酸代謝と $\mathrm{VB}_{12}$, 葉酸}

悪性貧血骨髄の巨赤芽球（図 1 ) の cell cycle は ${ }^{3}$ H-thymidineを用いた autoradiography に

* Drug-induced megaloblastic anemia

** 国立東京第一病院内科, 東京大学医学部第三内 科

Seitoku Fujioka: National Tokyo First Hospital and The Third Dept. of Internal Medicine, University of Tokyo.

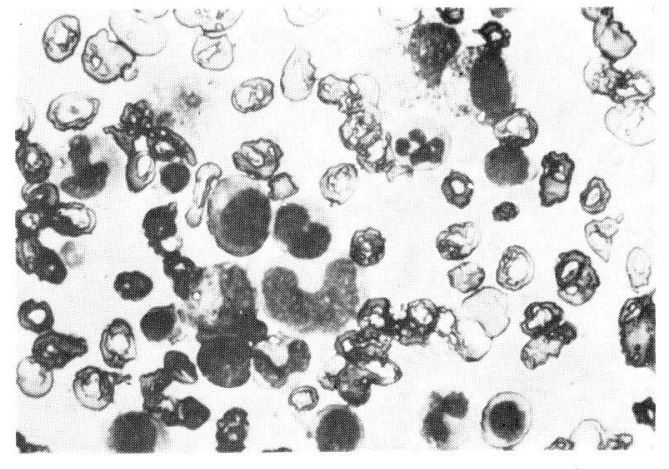

図 1 悪性貧血患者の巨赤芽球性骨瞇像 (骨膸穿刺液のWright 染色標本)

よって研究された。標識率は正常の骨髄芽球に 比べて同程度かむしろ増加していたが3) 5), 単 位時間あたりの grain count は低下していたの で6)，DNA 合成が充進していると言うよりは， その障害による DNA 合成期 ( $\mathrm{S}$ 期) の延長が あると考えられた。 autoradiography による標 識と共に紐胞の DNA 含量を Feulgen 染色で 测定し，正常の赤芽球では $\mathrm{S}$ 期の DNA 含量 をもつ細胞はすべて ${ }^{3} \mathrm{H}$-thymidine で標識され ているのに悪性貧血骨䯣では $\mathrm{S}$ 期の細胞で標識 されないものが多く見いだされた4)5). DNA 量 が $\mathrm{S}$ 期の細胞, すなわら $2 \mathrm{C}$ から $4 \mathrm{C}$ にある 細胞は DNA 合成期にあるはずで当然に ${ }^{3} \mathrm{H}$ thymidine を取り込导が，覀性貧血の巨赤芽球 ではこれが㠇められないものがあるので， $\mathrm{S}$ 期 で DNA 合成が停止したり，遅延したりして いることが明らかである。 DNA 量の分布をみ ると，巨赤芽球で $4 \mathrm{C}$ の細胞が多く， $\mathrm{G}_{2}$ 期の 延長が認められている。染色体の構造にも acentric fragments p gaps などの異常が見いだ され(4)7，一般に染色体の収縮が 不良で長さの 長いものがあり8)，分裂異常を考光させる配列 


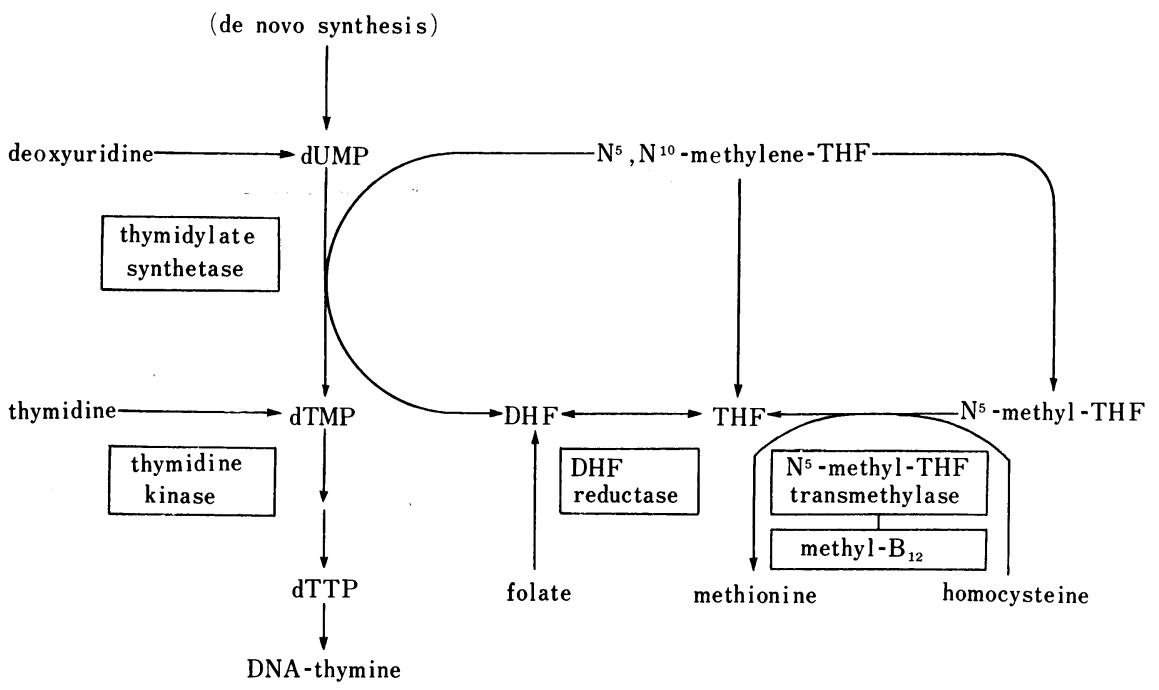

図 2 Thymidylate 生合成と葉酸誘導体执よび $\mathrm{VB}_{12}$ の関係 ${ }^{33)}$

を示す場合もある。これらの变化は $\mathrm{VB}_{12}$ 欠乏 に由来するもので， $\mathrm{VB}_{12}$ の注射によって速や かに正常に戻ることが確かめられている。この ように $\mathrm{VB}_{12}$ の欠乏が赤芽球の DNA 合成を障 害し, 巨赤芽球を産生させると考えられるが, $\mathrm{VB}_{12}$ は $\mathrm{DNA}$ 合成系のどの反応に関与寸るの であろらか。

methylfolate block 説 : Killmann や Metz, Herbert らによれば，正常骨髄の細胞を in vitro で培養し，培養液に放射性 deoxyuridine を 加えると DNA 合成をしている細胞に摂取され るが，悪性貧血骨髄では転入がおこりにくい9） 10). 培養液に $\mathrm{VB}_{12}$ を加えると一部転入が回復 し，葉酸を加えることにより正常骨髄と同様に 摂取されることが観察された。この実験から $\mathrm{VB}_{12}$ は葉酸を介して DNA 合成に関係してい ることが推定され，しかも deoxyuridine が悪 性負血骨䯣で DNA に転入され難いことから， $\mathrm{N}^{5}, \quad \mathrm{~N}^{10}$-methylene tetrahydrofolate を補酵素と して deoxyuridylate $か ら$ deoxythymidylate 合成される反応の部位が障害されていると考学 られた (図 2 参照). homocysteine から methionine の生合成には methyl-B 12 が補酵素とし て関与しているので1112)， $\mathrm{VB}_{12}$ の欠乏で tetrahydrofolate の産生が抑制され， $\mathrm{N}^{5}$-methyl-tetrahydrofolate が蓄積する。したがって tetrahy- drofolate が不足し, thymidylate cycle の一連 の反応が進行せず, deoxythymidylate の de novo 合成が低下寸る 結果になる。実際に悪性貧 血の症例で血漿中の $\mathrm{N}^{5}$-methyl-tetrahydrofolate が増加していることを示す報告もある1314)，乙 かし，葉酸值が高值であったり，食慨中の充分 な葉酸が吸収されて tetrahydrofolate に変わり 得ると考えられるよらな悪性筫血でも巨赤芽球 を示す例つあることから， $\mathrm{VB}_{12}$ の作用を methylfolate block 説のみからでは説明し得ない ように思われる。家族性におこった $\mathrm{VB}_{12}$ 反応 性の巨赤芽球性貧血の骨䯣で調べた最近の報告 では deoxyuridine が正常に取り込まれている ので15)この問題に関してはさらに詳細な検討が 望まれる。

Ribonucleotide 還元酵素説 : Harvard 大学 の Beck らは悪性貧血の巨赤芽球の model と して $\mathrm{VB}_{12}$ 欠乏培地で培養された Lactobacillus leichmannii について研究した ${ }^{16)}$.この菌は $\mathrm{VB}_{12}$ 欠乏培地で DNA 合成が抑制され，増殖が阻止 されるが，菌体が変化して長さや巾が大きくな る. この現象は正常赤芽球が悪性貧血で DNA 合成が障害されて巨赤芽球に変化するのと類似 している。この長大化した菌では ribonucleotides 含量は増加し, deoxyribonucleotides 㥛端 に減少していた。 $\mathrm{VB}_{12}$ を加えることにより， 
表 1 悪性貧血骨膸と L. leichmannii 酵素による ribonucleotides 還元に及ぼす coenzyme- $\mathrm{B}_{12}$ の效果 ${ }^{22)}$

\begin{tabular}{|c|c|c|c|c|c|c|}
\hline \multirow{2}{*}{ 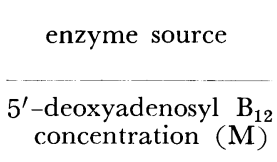 } & \multicolumn{6}{|c|}{$\begin{array}{l}\text { substrate dCDP formed } \\
\quad(\text { pmoles/mg protein } / \text { hour })\end{array}$} \\
\hline & & 0 & $10^{-7}$ & $10^{-6}$ & $10^{-5}$ & $10^{-4}$ \\
\hline bone marrow & CDP & 64 & 56 & 70 & 78 & 72 \\
\hline L. leichmannii & CTP & 29 & 1679 & 1903 & 2063 & 2051 \\
\hline $\begin{array}{l}\text { L. leichmannii } \\
\text { plus bone marrow }\end{array}$ & СTP & & 1462 & 1974 & 1904 & \\
\hline bone marrow & СТP & 14 & 12 & 10 & 9 & \\
\hline
\end{tabular}<smiles>CN(Cc1cnc2nc(N)nc(N)c2n1)c1ccc(C(=O)NC(CC(=O)O)C(=O)O)cc1Cl</smiles>

Methotrexate<smiles>O=c1nc(O)c(F)c[nH]1</smiles>

5-Fluorouracil

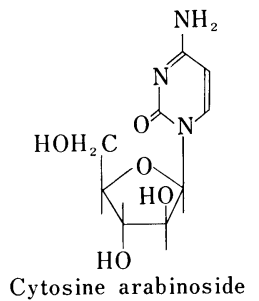

図 3 抗白血病剤 Methotrexate, 5-Fluorouracil, Cytosin arabinoside の構造式

de reductase を介していることが認められた が，巨赤芽球に関しては説明できない，巨赤芽 球のなかに DNA 前駆物質生合成に直接関係す る酵素で $V B_{12}$ requirement のものが存在する のかぞうか現時点では不明である.

\section{II. 抗白血病剤による巨赤芽球}

methotrexate : 葉酸拮抗剤として知られる methotrexate(図 3 ) を使用中に巨赤芽球が出現 し，大赤血球性貧血が抗こり，過分葉核白血球 が認められた症例が報告されている27)。この場 合, 白血球や血小板も極度に減少した。 methotrexate は葉酸を還元し活性型の tetrahydrofolate に変える酵素 dihydrofolic reductase と強 固に結合して酵素作用を阻害することが知られ ているので28), この場合の巨赤芽球産生の機序 は葉酸欠乏症と同様で，本来の意味の巨赤芽球 と形態の区別はつき難いと考えられよう。葉酸 欠乏の場合 thymidylase cycle を介して deoxythymidylate $の$ de novo 合成の阻止や purine 生合成の阻害によって DNA 前駆物質の生合成 が抑制され，赤芽球の DNA 合成が障害され る. 長期に少量の methotrexate を投与する時 は特に巨赤芽球性貧血の発生に注意すべきであ 


$$
\begin{aligned}
& \mathrm{OH} \\
& 1 \\
& \mathrm{NH} \\
& 1 \\
& \mathrm{C} \mathrm{O} \\
& 1 \\
& \mathrm{NH}_{2}
\end{aligned}
$$

Hydroxyurea<smiles>Sc1ncnc2[nH]cnc12</smiles>

6-Mercaptopurine<smiles>O=[P@@](CCCl)(CCCCl)OCCCCl</smiles>

Cyclophosphamide

図 4 抗白血病剂 Hydoroxyurea, 6-Mercaptopurine, Cyclophosp.ramide の構造式

る.しかし， 経過中に細胞の dihydrofolic redutase が増加して副作用を抽えることが知られ ており ${ }^{29)}$ ，白血病治療の際はこのため耐性が発 現して他の薬剤に変えなければならなくなる場 合がある。

5-Fluorouracil (5 FU)：5 FU (図 3) 投与後 24時間で $\mathrm{M}$ ：E 比が増加し, 後骨髄球の核が 薄く細網様になり，仁が著明になる ${ }^{30)}$ ，48時間 後に巨赤芽球が出現するが，この場合にも thymidylate synthetase 反応の部位で阻害がおこる ので31)32)，葉酸欠乏による pyrimidine 合成の 低下と同様に deoxythymidylate $の$ de novo 生 合成が抑制される， $5 \mathrm{FU} に よ り$ 細胞の thymidine kinase 活性が上昇して salvage pathway に よる deoxythymidylate 合成が進むことは骨髄 細胞でも知られている33). methyl-folate block 説によれば deoxythymidylate の de novo 合成 阻害は $\mathrm{VB}_{12}$ 欠乏の場合に関与しているので, $5 \mathrm{FU}$ による巨赤芽球は悪性貧血の場合と同様 な機序によって生じたと考えられるので興味深 い。ただし $5 \mathrm{FU}$ はRAに転入して蛋白合成 に影響するのでさらに複雑になる34).

cytosine arabinoside (ara-C) : ara-c (図 3) 投与により数日以内に巨赤芽球が骨髄に出現す る35). 巨赤芽球の数は投与量に関係しており, $3 \mathrm{mg} / \mathrm{kg}$ 連日投与で赤芽球の 20 から $30 \%$ が巨赤 芽球になり，30mg/kg では 70 から $80 \%$ が巨赤 芽球に変化する。赤芽球の中でもっとも著明に 巨赤芽球になるのは成熟した正染性赤芽球で, 非常に大きな染色質の loose な核が現われるが， 幼若赤芽球では大きさも核の变化もそれ程に著 しくはない. ara-Cにより巨後骨髄球や多核白血 球が出現するのは悪性貧血の場合に似ている。 位相差顕微鏡像では核は内部構造をもたず，悪 性貧血の巨赤芽球とは内容が異なる，分裂異常 や染色体異常も扎こり，多核巨赤芽球が生じる ことも報告されている ${ }^{36)}$. ara-C の抗腫瘍作用 は deoxycytidine を与えることにより軽減する ので37)， deoxycompound を合成する経路であ る ribonucleotide 還元が関与すると考えられた が，抽出された ribonucleotide reductase によ る cell free の実験では否定的である ${ }^{38)}$. 燐酸化 された ara-C は DNA の polymerization を抑 制する効果をもつ ${ }^{39}$.

Hydroxyurea : ribonucleotide reductase $\mathrm{VB}_{12}$ を補酵素とするか興味がもたれたが，先 に述べたように L. leichmannii と異なって人 の骨髄では関係しないことが分った ${ }^{22)}$. この酵 素に作用する抗白血病剤は hydroxyurea（図 4)

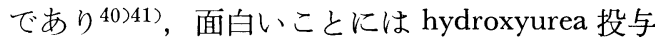
により巨赤芽球性骨䯣が惹起された ${ }^{42)}$ ，この薬 剂は他に作用もするので，影響は単一ではない が，巨赤芽球産生機序を考える上で非常に示唆 に富んでいる。

6-mercaptopurine (6 MP) : $6 \mathrm{MP}$ (図 4) の投与中にも巨赤芽球性骨䯣はおこり得る ${ }^{43)}$. 6 MP で完全寛解した 10 名の白血病患者の内 9 名に巨赤芽球が出現し，巨後骨䯣球や過分葉核 白血球も観察された。対照として methyl-glyoxal-bis-guanylhydrazone (methyl-GAG) で治療し た群には巨赤芽球は認められていないが，両薬 剤の使用量が副作用の強さによって異なるので 骨髄に与える影響も違うと考兄られ，厳密な意 味では比較は困難であろう。6 MP の作用機序 についてはこれまで多くの研究がなされている が，inosine-1- 燐酸から guanine-1-燐酸が 合成 される経路を阻害したり ${ }^{44)}$, hypoxanthine と guanine phosphoribosyl transferase に作用した 
りするらしい45). いずれにしても核酸前駆物質 である purine 生合成を障害する結果になる. 葉酸欠乏の場合，もっ之前の段階で de novo purine 生合成が阻害されるので $6 \mathrm{MP}$ でもその 類似が求められよう.

cyclophosphamide : 種々知られているアル キル化剤の中で cyclophosphamide (図 4) によ る巨赤芽球の出現が報告されている46). アルキ ル化剂は DNA の二本鎖にまたがって結合し， 細胞の分裂增殖を抑制するのが主要な作用と考 えられている ${ }^{47)}$. 悪性貧血の巨赤芽球でも tetraploid の細胞が増し，染色体の異常や分裂異 常像が見られるが，アルキル化剂による分裂や 増殖の抑制によっても巨赤芽球になり得るので あるう。

このよらに作用機序の異なる各種の抗白血病 剂の使用により骨髄中に巨赤芽球が出現寸る場 合があるが，薬剂を使用しなくても白血病のよ らな疾患に罹患しているだけで巨赤芽球が認め られる例があるし， $\mathrm{VB}_{12}$ や葉酸值が検討され ていないと，その欠乏が合併している可能性も あるので注意を要する。

\section{III. 抗痙攣剤による巨赤芽球性貧血}

抗痤攣剂として primidone, diphenylhydantoin, phenobarbital (図 5 ) などを長期に投与 されているてんかん患者の約30\%に骨髄中に巨 赤芽球が出現すると言われている。 この内で巨 赤芽球性負血をおこすのはそれ程多くはない が，重症な貧血になる場合がある。 diphenylhydantoin, primidone が巨赤芽球性貧血を掞こす 頻度が高いが， phenobarbital のみの投与によ っても惹起される例がある48) 54). これらの薬剤 による貧血発生の正確な機構は不明な点が多い が，血清や赤血球内の葉酸值が非常に低下し て抒り, 葉酸の吸収との関係が研究されてい る55) 57). 葉酸恃食物中の folate-heptaglutamte が小腸の conjugase により分解を受けて吸収さ れるが, diphenylhydantoin によりこの作用が 抑制される58)59). dihydrofolic reductase や他の 活性型葉酸に関係した酵素を阻害するといら成 績は得られていない, primidon は葉酸要求性<smiles></smiles>

Phenobarbital<smiles>CCC1(c2ccccc2)C(=O)NCNC1=O</smiles>

Primidone (2-desoxyphenobarbital)<smiles>O=C1N=C(O)NC1(c1ccccc1)c1ccccc1</smiles>

Diphenylhydantoin

図 5 抗痤攣剤 Phenobarbital, Primidone, Diphenylhydantoin の構造式

の C. fasciculate の増殖を抑制する ${ }^{60)}$. barbituric acid \& E. coli mutant の増殖を抑制する が，この効果は uracil を加えることで正常に 戻る ${ }^{61)}$ ，骨髄て対する作用は不明である，血清 $\mathrm{VB}_{12}$ もやや低值の傾向にある ${ }^{62)}$. 抗痤攣剂 による巨赤芽球性貧血は薬剂投与を中止すると 一時的に回復するが，再発する場合がある。葉 酸投与によって全例が回復し， $\mathrm{VB}_{12}$ のみでも 半数は造血がおこる. 両者の投与によって巨 赤芽球性貧血は治療される63)。ただし，葉酸や $\mathrm{VB}_{12}$ による治療で貧血は回復するが，てんか んの発作の回数が増加し, 発作を調節するのが 困難になることがある ${ }^{53) 64) . ~}$

\section{IV.その他の薬剤や中毒による 巨赤芽球}

感染症に対する化学療法剂で巨赤芽球性骨䯣 が怙こることが知られている，特に Chloramphenicol による巨赤芽球の出現は臨床的に経験 することが比較的に多いよらである65)．化学療 法剂や抗痤攣剂は骨髄の機能低下をもたらし， 再生不良性貧血を掞こすことが知られており， 巨赤芽球出現は骨䯣低形成の前段階的な意味が あるかも知れない，同じように再生不良性貧血 をもたらすベンゾール中毒でも巨赤芽球の出現 を見ることがある ${ }^{66)}$ ．巨赤芽球と骨䯣低形成の 
関係は注目さるべきであるが，まだ十分に解明 されていない。

\section{結語}

巨赤芽球性貧血は $\mathrm{VB}_{12}$ や葉酸の欠乏で通常 は打こる， $\mathrm{VB}_{12}$ や葉酸の生化学的機能と悪性 貧血の巨赤芽球で認められる DNA 合成障害と の関係について最近の知見を紹介した。抗白血 病剤による巨赤芽球の出現機序を抗白血病剂の 作用との関連で $\mathrm{VB}_{12}$ や葉酸欠乏の場合と比較 した，抗痤攣剂でも巨赤芽球性貧血になる例が あり，その機序については葉酸の吸収障害が一 つの原因と考えられている。

\section{文献}

1) Wintrobe, M. M.: Clinical Hematology (6 thed) 502, 1968, Lea \& Febiger, Philadelphia.

2) Castle, W. B.: Am. J. Med. Sci., 178; 748, 1929.

3) Schmid, J. R., Moeschlin, S. \& Haegi, V.: Acta Haematol., 32; 65, 1964.

4) Menzies, R. C., Crossen, P. E., Fitzgerald, P. H. \& Gunz, F. W.: Blood, 28; 581, 1966.

5) Wickramasinghe, S. N., Cooper, E.H. \& Chalmers, D. G.: Blood, 31；304, 1968.

6) Yoshida, Y., Toda, S., Shirakawa, S., Wakisaka, G. \& Uchino, H.: Blood, 31; 292, 1968.

7) Heath, C. W. Jr.: Blood, 31; 800, 1966.

8) Powsner, E. R. \& Berman, L.: Blood, 26; 784, 1965.

9) Killmann, S. A.: Acta, Med. Scand., 175; 483, 1964.

10) Metz, J., Kelly, Q., Swett, V.C. Waxman, S. \& Herbert, V.: Brit. J. Haematol., 14; 575, 1968.

11) Buchanan, J. M., Elford, H.L.. Loughlin, R. E., McDougall, B.M. \& Rosenthal, S.: Ann. N. Y. Acad. Sci. 112; 756; 1964.

12) Loughlin, R. E., Eltord, H. L. \& Buchanan, J. M.: J. Biol. Chem., 239; 2888, 1964.

13) Herbert, V. \& Zalusky, R.: J. Clin. Invest., 41；1263, 1962.

14) Waters, A. H. \& Mollin, D. L.: Brit. J. Haematol., 9; 319, 1963.

15) Lampkin, B. C., Pyesmany, A., Hyman, C. B., \& Hammond, D.: Bloob, 37; 615, 1971.

16) Beck, W. S., Goulian, M. \& Koshket, S.:
Trans. Assoc. Am. Physiol., 78; 343, 1965.

17) Blakley, R. L. \& Barker, H. A.: Biochem. Biophys. Res. Commun., 16; 391, 1964.

18) Beck, W.S. \& Hardy, J.: Proc. Natl. Acad. Sci., 54; 286, 1965.

19) Abrams, R.: J. Biol. Chem., 240; PC 3697, 1965.

20) Holmgren, A., Reichard, P. \& Thelander, L.: Proc Natl. Acad. Sci., 54; 830, 1965.

21) Reichard, P.: J. Biol. Chem., 237; 3513, 1962.

22) Fujioka, S. \& Shilber, R.: Biochem. Biophys. Res. Commun., 35; 759, 1969.

23) Fujioka, S. \& Silber, R.: J. Lab. Clin. Med., 77; 59, 1971.

24）藤岡：代謝，8；90，1971

25) Moore, E. C. \& Hurlbert, R. B.: J. Biol. Chem., 241；4802, 1966.

26) Fujioka, S. \& Silber, R.: J. Biol. Chem., 245; 1688, 1970.

27) Borrie, P. \& Clark, P. A.: Brit. Med. J., i, 1339, 1966

28) Werkheiser, W. C.: J. Biol. Chem., 236; 3888, 1961.

29) Bertino, J. R., Huennekens, F.M. \& Gabrio, M.: Clin. Res., 9; 103, 1961.

30) Brennan, M.J., Vaitkevicius, V.K. \& Rebuck, J. W.: Blood, 16; 1535, 1960.

31) Cohen, S. S, Flaks, J.G., Barner, H.D. Loeb, M.R. \& Lichtenstein, J.: Proc. Natl. Acad. Sci., 44; 1004, 1958.

32) Bosch, L., Harbers, E. \& Heidelberger, C.: Canc. Res., 18; 335, 1958

33）藤岡，小峰，高久，中尾：医学のあ印み， 64; 400, 1968.

34) Horowitz, J. \& Changaff, F.: Nature, 184; 1213, 1959.

35) Talley, R.W. \& Vaitkevicius, V. K.: Blood: 21; 352, 1963

36) Bell, W. R., Whang. J. J., Carbone, P. P., Brecher, G. \& Block, J. B.: Blood, 27; 771, 1966.

37) Chu, M.Y. \& Fischer, G.A.: Biochem. Pharmac., 11; 423, 1962.

38) Moore, E. C. \& Cohen, S. S.: J. Biol. Chem., 242; 2116, 1967.

39) Furth, J. J. \& Cohen. S. S.: Canc. Res., 28; 2061, 1968

40) Frenkel, E. P., Skinner, W. N. \& Smiley, J. D.: Canc. Chemother. Rep., 40; 19, 1964. 
41) Krakoff, I.H., Brown, N.C. \& Reichard, P.: Canc, Res., 28; 1559. 1968.

42) Frenkel, E. P. \& Arthur, C.: Canc. Res. 27; 1016, 1967.

43) Levin, R. H., Brittin, G. M. \& Freireich, E. J.: Blood, 21; 689, 1963.

44) Bennett, L. L. Jr., Simpson, L., Golden, J. \& Banker J. L.: Canc. Res., 23; 1574, 1963.

45) Atkinson, M. R. \& Murray, A. W.: Biochem. J., 94; 64, 1965.

46) Berndt, H. \& Hiller, I.: Klin, Wschr., 43; 333, 1965.

47) Yamamoto, N. \& Naito, T.: Science, 150; 1603, 1965.

48) Mannheimer, E., Pakesch, F., Reimer, E. E. \& Vetter, H.: Medsche Klin., 47; 1397, 1952.

49) Girdwood, R.H. \& Lenman, J. A. A.: Brit. Med. J., i, 146, 1956.

50) Benians, R. C. \& Hunter, R.A.: J. Ment Sci., 103; 606, 1957.

51) Christenson, W.N., Ultmann, J. E. \& Roseman, D. M.: J. Am. Med. Ass., 163; 940, 1957.

52) Newman, M. J. D. \& Sumner, D. W.: Blood, 12; 183, 1957.

53) Chanarin, I., Laidlaw, J., Loughridge, L. W.
\& Mollin, D. L.: Brit. Med. J., i, 1099, 1960.

54) Penny, J. L.: Archs. Intern. Med., 111; 744, 1963.

55) Meynell, M. J.: Lancet, i, 487, 1966.

56) Dahlke, M. B. \& Mertens-Roesler, E.: Blood, 30; 341, 1967.

57) Hepner, G. W.: Brit. J. Haemat., 16; 241, 1969.

58) Hoffbrand, A. V. \& Necheles, T. H.: Lancet, ii, 528, 1968.

59) Rosenberg, I.H., Godwin, H. A., Streiff, R. R. \& Castle, W. B.: Lancet, ii. 530, 1968.

60) Baker, H., Frank, O., Hutner, S. H., Aaronson, S., Ziffer, H. \& Sobotka, H.: Experientia, 18; 224, 1962.

61) Woods, D. D.: Biochem. J., 36; 3, 1942.

62) Malpas, J. S., Spray, G. H. \& Witts, L. J.: Brit. Med. J., i, 955, 1966.

63) Druskin, M.S., Wallen, M. H. \& Bonagura, L.: New. Engl. J. Med., 267; 483, 1962.

64) Reynolds, E. H.: Lancet, i, 1086, 1967.

65) Rich. M. L., Ritterhoff, R.J. \& Hoffman, R. J.: Ann. Int. Med., 33; 1459, 1950.

66）藤岡, 他：第 9 回日本臨床血液学会総会抄録, 48, 1967. 